\title{
Preparation and process optimization of microbial organic copper as a feed additive
}

\author{
[Preparação e otimização do processo de cobre orgânico microbiano \\ como aditivo alimentar] \\ Y.R. Wei ${ }^{\# 1}$, G.X. Wei $i^{\# 1}$, Z.Y. Wang ${ }^{\# 2}$, D.D. $X i e^{1}$, \\ X.Y. Fan ${ }^{1}$, Z.P. Jia ${ }^{1}$, J. Zhang ${ }^{3 *}$, X.G. Zhang ${ }^{1 *}$ \\ ${ }^{1}$ School of Life Science and Engineering - Lanzhou University of Technology - Key Laboratory of \\ Screening and Processing in new Tibetan medicine of Gansu Province - Gansu, China \\ ${ }^{2}$ Animal Disease Prevention and Control Center of Lanzhou City - Gansu, China \\ ${ }^{3}$ College of life sciences - Northwest Normal University - Gansu, China
}

\begin{abstract}
As an essential trace element for animals, copper significantly contributes to the growth and health of animals. Compared to inorganic trace elements, organic trace elements are better supplements; notably, they are acquired through microbial transformation. Therefore, we screened for copper-enriched microorganisms from high copper content soil to obtain organic copper. Sodium diethyldithio carbamate trihydrate was applied as a chromogenic agent for determining micro amounts of intracellular copper through spectrophotometry. In total, 50 fungi were isolated after the successful application of the screening platform for copper-rich microbes. Following morphological and molecular biology analyses, the N-2 strain, identified as Aspergillus niger sp. demonstrated showed better copper enrichment potential than others. Notably, the strain tolerance to copper was nearly thrice that of Saccharomyces cerevisiae, up to $1600 \mathrm{mg} / \mathrm{L}$. The content of the organic bound copper was $22.84 \mathrm{mg} \mathrm{Cu} / \mathrm{g}$ dry cell. Using the Central Composite Design (CCD) response surface method, we optimized the fermentation condition (inoculation amount, $13 \%$; temperature, $28^{\circ} \mathrm{C} ; \mathrm{pH}, 5.0$ ). Compared to the original strain results under the single factor fermentation condition, we reported an increase by $24.18 \%$ under the optimized conditions. Collectively, these findings provide a reference for uncovering new and low-cost organic copper additives.
\end{abstract}

Keywords: organic copper, screening, identification, process optimization

\section{RESUMO}

Como elemento traço essencial para os animais, o cobre contribui significativamente para o crescimento e saúde dos animais. Comparado aos oligoelementos inorgânicos, os oligoelementos orgânicos são melhores suplementos; notavelmente, eles são adquiridos através de transformação microbiana. Portanto, nós selecionamos microorganismos enriquecidos com cobre de solos com alto teor de cobre para obter cobre orgânico. O carbamato de sódio diethyldithio trihidratado foi aplicado como agente cromogênico para a determinação de micro quantidades de cobre intracelular através da espectrofotometria. No total, 50 fungos foram isolados após a aplicação bem sucedida da plataforma de triagem para micróbios ricos em cobre. Após análises morfológicas e de biologia molecular, a cepa N-2, identificada como Aspergillus niger sp. demonstrou um melhor potencial de enriquecimento de cobre do que outras. Notavelmente, a tolerância da estirpe ao cobre foi quase três vezes maior que a da Saccharomyces cerevisiae, até 1600mg/L. $O$ conteúdo de cobre ligado orgânico era de 22,84mg Cu/g de célula seca. Usando o método de superfície de resposta Central Composite Design (CCD), nós otimizamos a condição de fermentação (quantidade de inoculação, 13\%; temperatura, 28C; pH, 5,0). Em comparação com os resultados da deformação original sob a condição de fermentação de fator único, relatamos um aumento de 24,18\% sob as condições otimizadas. Coletivamente, estas descobertas fornecem uma referência para descobrir novos aditivos de cobre orgânico de baixo custo.

Palavras-chave: cobre orgânico, triagem, identificação, otimização do processo

*Corresponding author: biodrug@163.com

Submitted: October 15, 2020. Accepted: February 19, 2021.

\#These authors contributed equally to this work 


\section{INTRODUCTION}

Animals utilize copper as an essential trace element, which is vital in forming numerous important oxidases in the body. In particular, copper plays crucial role in animal health and growth (Liu et al., 2016; Knop et al., 2017). Earlier, Braude et al. (1945) reported for the first time that adding 10 times the daily copper content to pig feed significantly improved their reproductive capacity. Subsequent studies also confirmed that high copper content obviously promotes the growth of pigs, increase the daily weight gain of weaned piglets, and improve feed efficiency (Braude, 1945). At present, supplementing high amounts of copper to feed has become the norm in animal husbandry. However, high doses of copper are associated with problems including its persistence in livestock and poultry, reduction in the quality of livestock products, and environmental harm caused by the unabsorbed portions (Liu et al., 2013; Wang et al., 2015). In some countries, such as China, the addition of copper in feed is restricted. Therefore, there is an urgent need for the breeding industry to urgently uncover a new and efficient additive copper source, which both comply with the national regulations and improve the production performance of pigs.

Based on the current understanding, inorganic copper sulfate is the most widely used source of copper in feed supplementation (Wu et al., 2014); however, it readily absorbs moisture and agglomerates; and exhibits a strong oxidation capacity and low bioavailability (Additives and Feed, 2011). Compared to inorganic copper sulfate, organic copper, such as those present in conjugation with various proteins, are characterized by strong aqueous solubility and easy digestibility and absorption, and improves the productivity of cows and calves (Marques et al., 2016). However, these organic copper sources are associated with drawbacks, for example, high production cost and imperfect manufacturing processes, which cannot offer solutions to the existing challenges posed by the addition of copper to feed.

Applying microorganisms as enrichment sources to obtain organic trace elements have increasingly attracted the attention of scholars and are focused on exploring the organic trace element additives. Evidence from an increasing number of studies shows that, under appropriate conditions, yeast can enrich and transform copper (Mrvčić et al., 2007; Lottermoser, 2009), manganese, (Barbulescu et al., 2010), selenium (EgressyMolnár et al., 2016), zinc (Wang et al., 2011), chromium (Liu et al., 2012), iron (Paš et al., 2007; Zhang et al., 2016), and other trace elements. The current processes and methods for organic copper microbial transformation mainly utilize the following protocol: edible fungus species expansion $\rightarrow$ separation and purification $\rightarrow$ copper tolerance screening $\rightarrow$ copper tolerance domestication $\rightarrow$ copper-rich rate determination (Mrvčić et al., 2007). Previous reports revealed that wild-type yeast exhibit limited tolerance to trace elements, including copper (Mrvčić et al., 2007), zinc (Wang et al., 2011), iron (Paš et al., 2007), and other inorganic substances as well as enrichment and transformation potential.

In addition, various methods, among them, ultraviolet mutagenesis, chemical mutagenesis, and protoplast fusion (Lee et al., 2011; Hou e Yao, 2012) have proven not satisfactory in elevating the tolerance of yeast to trace element enrichment (up to only $3000 \mathrm{mg} / \mathrm{L}$ for iron). Of note, studies regarding natural copper-rich microorganisms are rare; this has hampered the development of copper-rich microorganism resources, consequently limiting research on the microbial conversion of inorganic copper. The present study purposed to select better copper-rich microbial resources and high copper-resistant transformation strains from the natural environment. Of note, the organic copper additive was obtained through bioaccumulation and transformation of inorganic copper within cells. Thus, this study will provide a new method of producing inexpensive and green organic copper for aquaculture.

\section{MATERIALS AND METHODS}

Ezup column genomic DNA extraction kit was purchased from Shengong Biological Engineering Co., LTD. (Shanghai, China). Deionized water for the market wahaha purified water, copper powder purity is $99.59 \%$, and ammonium citrate, concentrated nitric acid, concentrated sulfuric acid, and copper sulfate reagents are analytical grade. The revived culture of wild type Saccharomyces cerevisiae was inoculated in $100 \mathrm{~mL}$ YPD liquid medium (1\% yeast extract, $2 \%$ glucose, and $2 \%$ tryptone peptone) containing 
100, 200, 300, 400, 500, 600mg/L Cu $\mathrm{Cu}^{2+}$ and cultured at $28^{\circ} \mathrm{C}$ for $3-7$ days. To evaluate the growth status of yeast, we employed the cell counting method with a blood cell counting plate.

Soil samples were collected from the Baiyin copper mine and its vicinity in the Gansu province. The surface soil was scraped off. Then, $100 \mathrm{~g}$ aliquots of soil at $5-10 \mathrm{~cm}$ depth were collected, and put in an envelope for subsequent analysis. Measurement of weight was taken for $1 \mathrm{~g}$ of the sampled soil, placed in a triangular bottle containing $99 \mathrm{~mL}$ sterile water, and oscillated evenly. This was followed by the preparation of 10-fold gradient dilutions of the soil samples, sequentially $\left(10^{-3}, 10^{-4}, 10^{-5}, 10^{-6}\right.$ and $\left.10^{-7}\right)$. Under sterile conditions, $0.2 \mathrm{~mL}$ soil diluted to the corresponding concentrations were spread evenly on PDA solid medium (200g potato, $20 \mathrm{~g}$ glucose, $20 \mathrm{~g}$ agar, $1000 \mathrm{~mL}$ water, $\mathrm{pH} 7.4-7.6)$ with an initial copper ion concentration of $500 \mathrm{mg} / \mathrm{L}$, then cultured at $28^{\circ} \mathrm{C}$ in a biochemical constanttemperature incubator for 3-7 days. Distinct single colonies of different were purified and cultured. The strains were given number codes and stored in the refrigerator.

Each of the newly screened strains was inoculated in PDA solid medium containing 800, 1000, 1200,

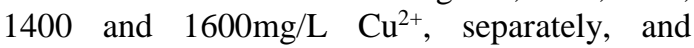
cultured at $30^{\circ} \mathrm{C}$ for 7 days. Colonies that showed satisfactory growth and stability in a highly concentrated $\mathrm{Cu}^{2+}$ environment were selected, then stored in slants (prepared using the above medium) at $-20^{\circ} \mathrm{C}$ for subsequent experiments. $\mathrm{N}$ 2 was purified by plating on PDA solid medium, and cultured at $28^{\circ} \mathrm{C}$ for 5 days until a single colony appeared. Using the method reported by Kurtzman et al. (2011) the phenotypic characteristics of the strain $\mathrm{N}-2$ were observed and described (Kurtzman et al., 2011). The total DNA of Strain N-2 was extracted using previous method reported by Lu et al., (2004) and was improved as follows: $\mathrm{N}-2$ was inoculated in PDA liquid medium, cultured at $28^{\circ} \mathrm{C}$ for 5 days, centrifuged at $5000 \mathrm{r} / \mathrm{min}$ for $10 \mathrm{~min}$.

The cells were washed twice with PBS, then washed twice with distilled water to collect the cells. Total DNA was extracted using the Ezup column fungal genomic DNA extraction kit. Primers $2234 \mathrm{C}$ and $3126 \mathrm{~T}$ amplified $18 \mathrm{~S}$ rDNA. The heat cycle scheme adopted was: $94^{\circ} \mathrm{C}$ for
$3 \mathrm{~min}, 94^{\circ} \mathrm{C}$ for $30 \mathrm{~s}, 56^{\circ} \mathrm{C}$ for $30 \mathrm{~s}, 72^{\circ} \mathrm{C}$ for $50 \mathrm{~s}$, $72^{\circ} \mathrm{C}$ for $7 \mathrm{~min}$, a total of 32 cycles. The PCR products were separated by $1 \%$ agarose gel electrophoresis and sent to Shanghai Biotechnology Engineering Service Center for sequencing. The sequencing results were submitted to the NCBI database for BLAST comparison, the homology comparison of typical strains was found by Clustal X2.0, and phylogenetic trees were constructed by Meta 7.0 software. (Edulamudi et al., 2011).

According to the Chinese Pharmacopeia, the intracellular copper content was evaluated via the diethyldithiosulfate spectrophotometric method (Farnsworth et al., 1984). Briefly, standard solution containing 0, 5.0, 10.0, 15.0, 20.0, and $25.0 \mu \mathrm{g}$ copper were transferred to a $125 \mathrm{~mL}$ graduated funnel, followed by the addition of ammonium citrate (5mL), ethylenediaminetetraacetic acid disodium solution, and phenol red indicator solution $(50 \mu \mathrm{L})$ and mixed; To the mixture, ammonia $(13 \mathrm{~mol} / \mathrm{L})$ was added. Then, cupreous reagent $(2.0 \mathrm{~mL})$ and carbon tetrachloride $(10.0 \mathrm{~mL})$ were added and shaken vigorously for $2 \mathrm{~min}$. Afterward, carbon tetrachloride was left to stand for layering, then filtered through absorbent cotton into a quartz cuvette. Absorbance measurement was taken at 440nm using carbon tetrachloride as the blank, after which a standard curve was generated.

We borrowed a protocol from our previous work to prepare the organic copper (Lottermoser, 2009). Cells were repeatedly centrifuged and subjected to six times wash with deionized water. After having dried completely to a stable mass in a digesting flask, nitric acid $(10 \mathrm{~mL})$ and perchloric acid $(4: 1, \mathrm{v} / \mathrm{v})$ were added to $0.3 \mathrm{~g}$ of the sample was used. A 30min incubation followed this in a digestion furnace till the contents turned translucent and left to cool. The solution was transferred to a $50 \mathrm{~mL}$ volumetric flask, and the volume was made up with deionized water. Measurement of the intracellular copper content was obtained according to the standard curve method described above.

The impact of different factors on the growth of copper-enriched strains and copper enrichment were evaluated as follows: I. Exactly $100 \mathrm{~mL}$ PDA liquid medium with $500 \mathrm{mg} / \mathrm{L}$ copper content was prepared in $500 \mathrm{~mL}$ Erlenmeyer flasks. Thereafter, $2 \%, 6 \%, 10 \%, 15 \%$, and $20 \% \mathrm{~N}-2$ strains were 
inoculated in each flask ( 3 per group). After 4 days of shaking $\left(30^{\circ} \mathrm{C}\right.$ at $\left.200 \mathrm{r} / \mathrm{min}\right)$, the cells were collected via centrifugation at $5000 \mathrm{r} / \mathrm{min}$ for 10 min, washed six times with $0.9 \%$ sodium chloride solution. Washed cells were placed in a dialysis bag, and dialyzed for $48 \mathrm{~h}$ until no free copper was detected. The samples were dried at $60^{\circ} \mathrm{C}$ to constant weight measurement of the intracellular copper content of bacteria was taken using the above method. II. After inoculation with $10 \% \mathrm{~N}$ 2 strain, the culture was placed in a shaking incubator at $30^{\circ} \mathrm{C}$ and $200 \mathrm{r} / \mathrm{min}$ for $0,16,24,48$, 72,96 , and $120 \mathrm{~h}$, after that cells were collected for further analyses as mentioned above. III. After inoculation with $10 \% \mathrm{~N}-2$ strain, the culture was placed in a shaking incubator at $200 \mathrm{r} / \mathrm{min}$ for 4 days at $20,25,30,35$, and $40^{\circ} \mathrm{C}$; thereafter the cells were collected for further analyses as mentioned above. IV. Exactly 100mL PDA liquid medium with copper content $(500 \mathrm{mg} / \mathrm{L})$ was prepared in $500 \mathrm{~mL}$ Erlenmeyer flasks; the initial $\mathrm{pH}$ was adjusted to 4.0, 5.0, 6.0, 7.0, 8.0, and 9.0 with dilute acid or alkali, as required.

To obtain optimal growth and copper enrichment of the enrichment strains, different factors, among them, the inoculation amount, fermentation temperature, and $\mathrm{pH}$, were varied. Further, their effects were analyzed using the surface response test. The Design expert 8.0.6 software was used to devise the CCD response surface test design scheme based on the single factor test results. The factor level of the CCD response surface design is outlined in Table S1. For data analysis the Design Expert 8.0.6 software was used. Factors with $P$ $<0.05$ were selected as the significance test criteria.

Table S1. Factors and level coding table of CCD (Central Composite Design) for incubation conditions of Aspergillus sp. N-2 strain

\begin{tabular}{|c|c|c|c|}
\hline Code & A:PH value & $\mathrm{B}: \mathrm{T}\left({ }^{\circ} \mathrm{C}\right)$ & C:Inoculum size $(\%)$ \\
\hline+1.682 & 8 & 42 & 25 \\
\hline+1 & 7 & 20 & 20 \\
\hline 0 & 5 & 28 & 13 \\
\hline-1 & 3 & 37 & 6 \\
\hline-1.682 & 2 & 15 & 2 \\
\hline
\end{tabular}

\section{RESULTS}

The activated wild-type $S$. cerevisiae was cultured in a copper-containing medium. Results demonstrated significant inhibition of the growth of the inoculated yeast with elevated copper ion concentration in the medium. Notably, the yeast did not grow in the medium with $600 \mathrm{mg} / \mathrm{L}$ copper ion. Similarly, the growth of yeast was significantly inhibited in a medium with $500 \mathrm{mg} / \mathrm{L}$ copper ion. Thus, with the initial copper ion concentration of $500 \mathrm{mg} / \mathrm{L}$, we screened for the copper-rich strain.

After the preliminary screening on PDA solid medium (containing $500 \mathrm{mg} / \mathrm{L} \mathrm{Cu}^{2+}$ ), we selected distinct single colonies for purification and culture. A total of 50 copper-rich strains were obtained. and inoculated in PDA solid medium containing 800, 1000, 1200, 1400, and $1600 \mathrm{mg} / \mathrm{L}$ $\mathrm{Cu}^{2+}$. Notably, 36, 22, 13, 7, and 4 copperresistant strains grew in the presence of $>800 \mathrm{mg} / \mathrm{L}$ $\mathrm{Cu}^{2+} ;>1000 \mathrm{mg} / \mathrm{L} \quad \mathrm{Cu}^{2+}, \quad>1200 \mathrm{mg} / \mathrm{L} \quad \mathrm{Cu}^{2+}$, $1400 \mathrm{mg} / \mathrm{L} \mathrm{Cu}{ }^{2+}$, and $>1600 \mathrm{mg} / \mathrm{L} \mathrm{Cu}{ }^{2+}$, respectively. Eventually, four highly copperresistant strains were screened and issued with the following codes: N-1, N-2, N-3, and N-4.

The sodium diethyldithiocarbamate-photometric method was used to evaluate the amount of copper enriched in the cells. The correlation analysis $\left(\mathrm{R}^{2}\right.$ $=0.994)$ results showed that determining the copper content can meet the requirements for this study (Figure. S1). To compare the potential of different strains to transform inorganic copper to organic copper under high copper conditions, we performed the test under the same conditions. After that, growth and intracellular organic copper content were evaluated. The intracellular copper content of the four strains $(\mathrm{N}-1, \mathrm{~N}-2, \mathrm{~N}-3$ and $\mathrm{N}-$ 4) were $14.99 \mathrm{mg} / \mathrm{g}, 22.84 \mathrm{mg} / \mathrm{g}, 17.57 \mathrm{mg} / \mathrm{g}$, and $11.95 \mathrm{mg} / \mathrm{g}$, respectively (Figure. 1). In particular, strain N-2 showed the largest intracellular copper enrichment, good growth status and large biomass. Notably, $\mathrm{N}-2$ was suggested to be a highly copper-enriched strain, thus could be used for follow-up studies. 


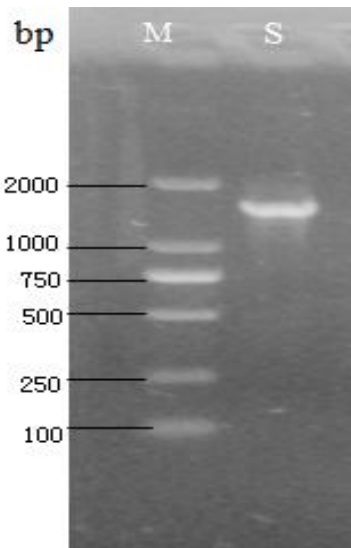

A

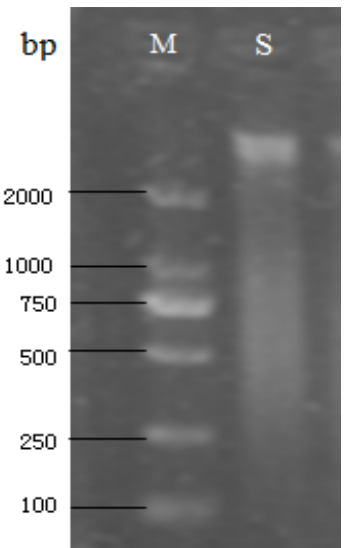

B

Figure S1. Agarose gel electrophoresis of DNA isolated from Aspergillus sp. N-2 strain. In here, S-A and S-B represent genomic DNA and 18s rDNA PCR isolated from Aspergillus sp. N-2 strain; M-A and M-B represent DNA marker, respectively.

A

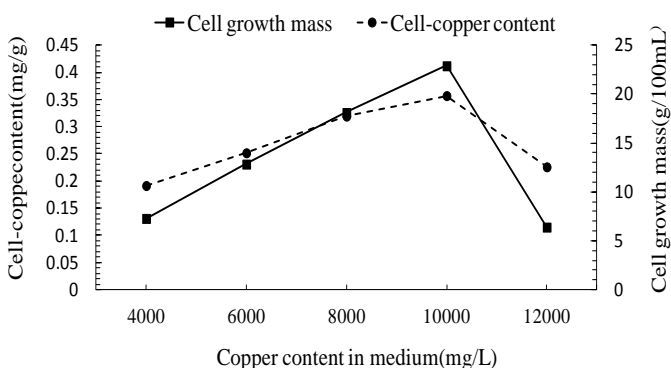

C

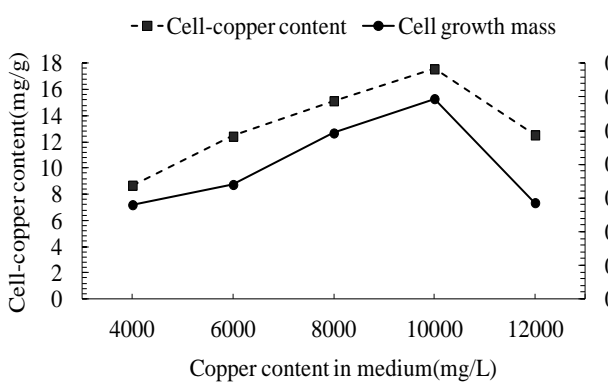

B

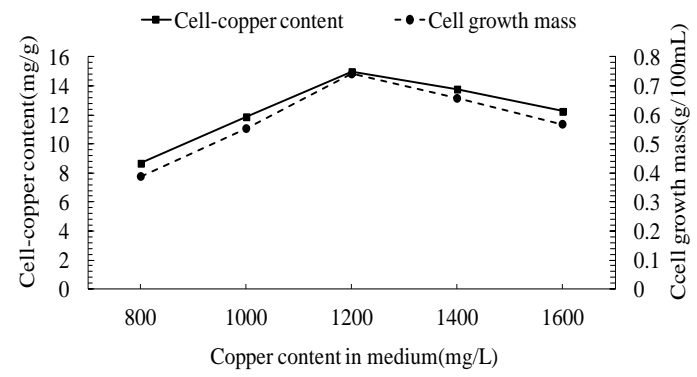

D

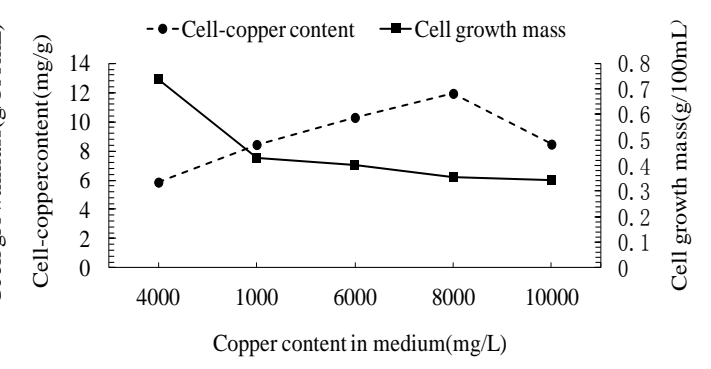

Figure 1. Determining the content of organic copper in different copper-enriched strains. In here, A-D represent strain $\mathrm{N}-1, \mathrm{~N}-2, \mathrm{~N}-3$ and $\mathrm{N}-4$, respectively.

Subsequently, the N-2 strain was cultured on PDA medium at $30^{\circ} \mathrm{C}$ for $96 \mathrm{~h}$. Morphologically, the colony was black, with fluffy surface protrusions and rough edges. The hyphae were yellowishwhite in the early growth stage and dark brown after sporulation in the later stage. The conidial spikes were spherical and divided. Podocytes were observed at the end of the spores (Figure. 2). The extracted genomic DNA of the copper-rich strain was analyzed via agarose gel electrophoresis. With the genomic DNA as the template, PCR amplification of 18s rDNA showed an intense band, at approximately $1500 \mathrm{bp}$ (Figure. S2). PCR product sequence was compared to those in the Genbank database via BLAST 


\section{Wei et al.}

analysis. Results revealed that the strain shared 99\% homology with the 18S rDNA sequence of Aspergillus niger. A phylogenetic tree was constructed generated based on the 18S rDNA

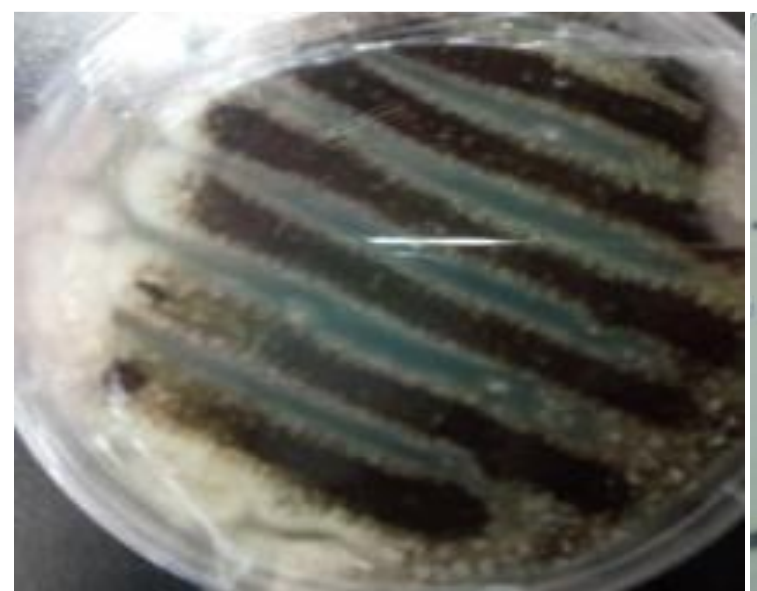

$\mathbf{A}$

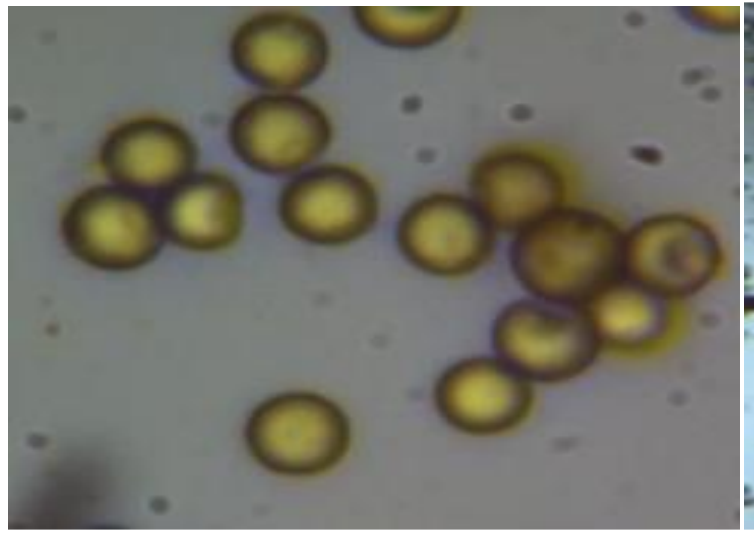

$\mathbf{C}$

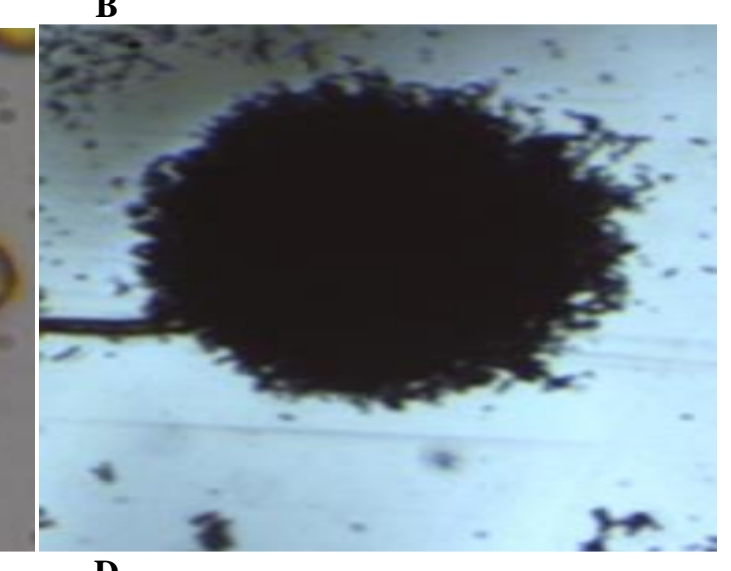

D

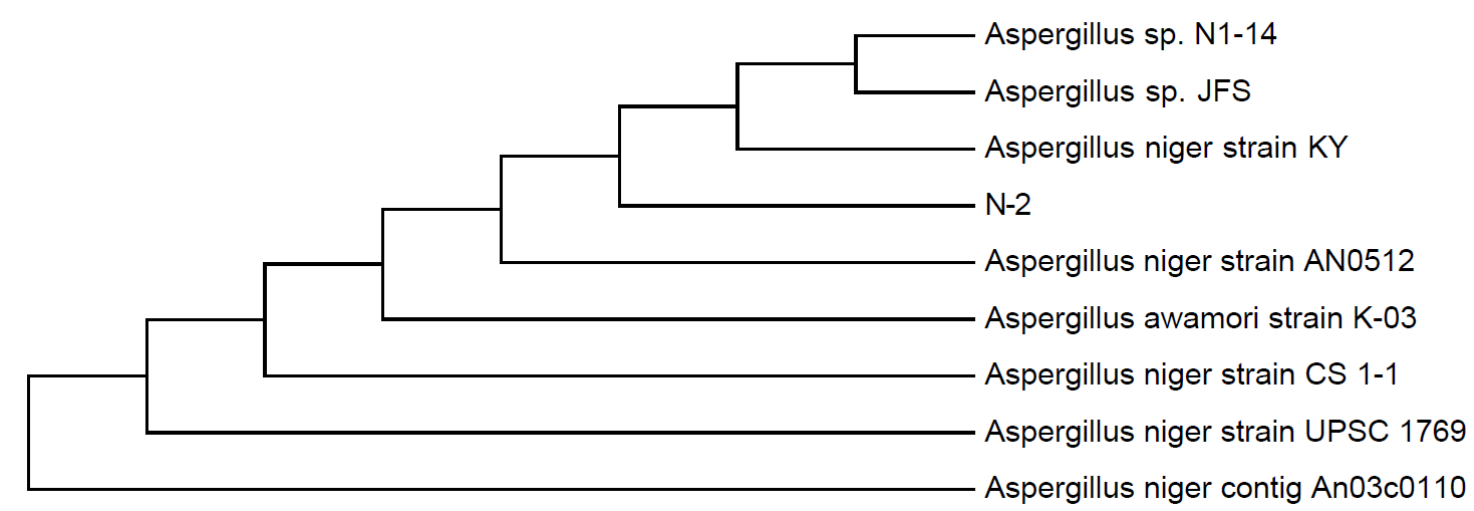

Figure 2. Phenotypic characteristics and phylogenetic dendrogram of Aspergillus sp. N-2 strain. In here, AD represent the colony morphology (A), microscopic morphology of stain (B), sporulation structure (C) and spore (D), respectively; (E) represents the phylogenetic dendrogram of Aspergillus sp. N-2 strain. 


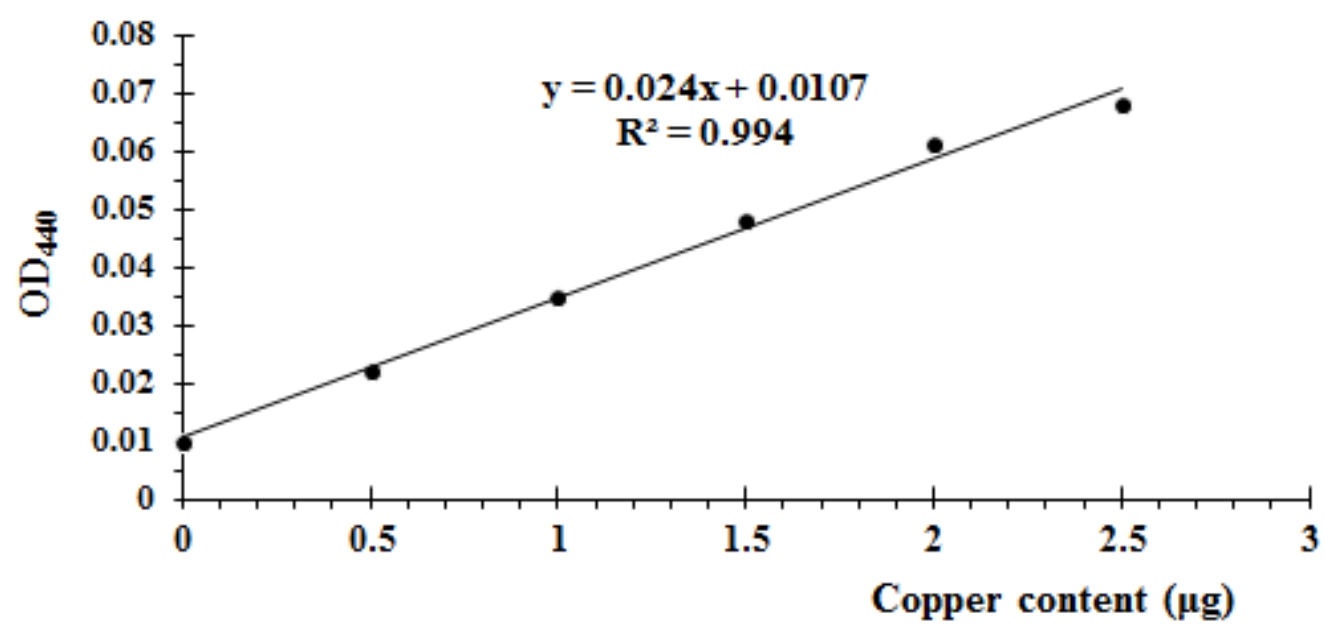

Figure S2. The standard curve for evaluating copper content.

The growth of the strain and the level of copper enrichment increased sequentially following an increment in the inoculation amount of the bacterial cells. The intracellular copper content and the growth of the bacterial cells were the highest at approximately $10 \%$ of the inoculation amount of the bacterial species. We deduced that with the inoculation amount of the bacteria at $10 \%$, the ratio of the number of bacteria to the number of nutrients in the medium was the most suitable; notably, the absorption of copper in the medium by the specific bacteria was optimal.

As depicted in Figure 3B, bacterial growth and the enrichment of copper gradually rose with prolonged fermentation time. At 96h culture time, the intracellular copper content and bacterial growth peaked, and after this period, cell growth decreased, then stabilized; simultaneously, the cells enriched the copper ions optimally. Furthermore, bacterial growth and copper enrichment were significantly limited in an acidic environment (Figure 3C). At a $\mathrm{pH}$ range of 5-7, strain N-2 exhibited a stable growth phase; the intracellular copper content did not fluctuate significantly. Besides, at $\mathrm{pH} 5$, the intracellular copper content and cell growth were relatively high.

Following an increase in culture temperature, the growth of the bacterial cells and the extent of copper enrichment increased significantly, peaking when the temperature exceeded $30^{\circ} \mathrm{C}$ (Figure 3D). The intracellular copper content and bacterial growth decreased at elevated temperature levels; this may be attributed to the close relationship of the activity of temperature with proteins, nucleic acids, and other biological molecules. High or low temperature reduces the activities of proteins and enzymes, thereby slowing bacterial metabolism. In this study, using the single factor test of the fermentation production process, three factors were found to exert the maximum influence on the growth and copper enrichment of strain $\mathrm{N}-2$, thus were selected for application in further experiments. The best conditions for every single factor were as follows: Optimum cultivation time, $96 \mathrm{~h}$; optimum temperature, $30^{\circ} \mathrm{C}$, the optimum strain inoculation amount, $10 \%$; optimal $\mathrm{pH}, 5$.

The CCD response surface design experimental scheme was applied; the experimental results are shown in Table 1. The quadratic multiple regression equation was generated via the Design Expert software as follows: $\mathrm{Y}=1.36+0.12 \mathrm{~A}$ $0.18 \mathrm{~B}-0.09 \mathrm{C}-0.83 \mathrm{AB}-0.83 \mathrm{AC}-0.11 \mathrm{BC}-0.62 \mathrm{~A}^{2}$ $0.44 B^{2}-0.46 C^{2} \quad\left(R^{2}=0.9853\right)$. In the regression equation, the response value is well-fitted $\left(\mathrm{R}^{2}\right.$ $=0.9853$ ). Results for the analysis of variance of this regression model are shown in Table 2 . Notably, the model was significant $(P<0.05)$, and the lack of fit was not significant $(P>0.05)$; therefore, the regression equation could comprehensively describe the true relationship between response value and various optimization factors for optimizing the most suitable fermentation conditions. 
A

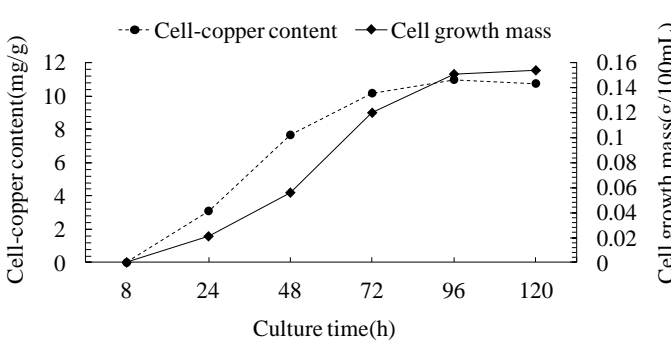

C

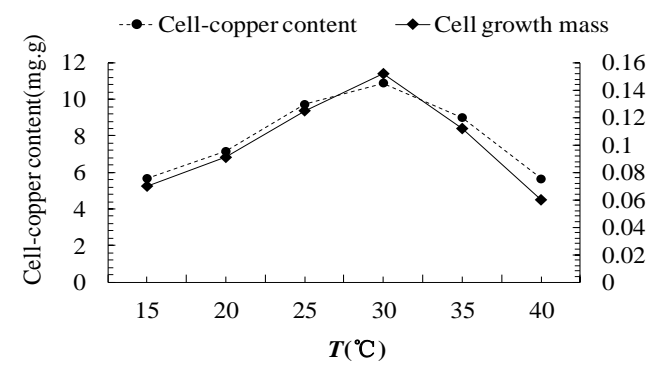

B

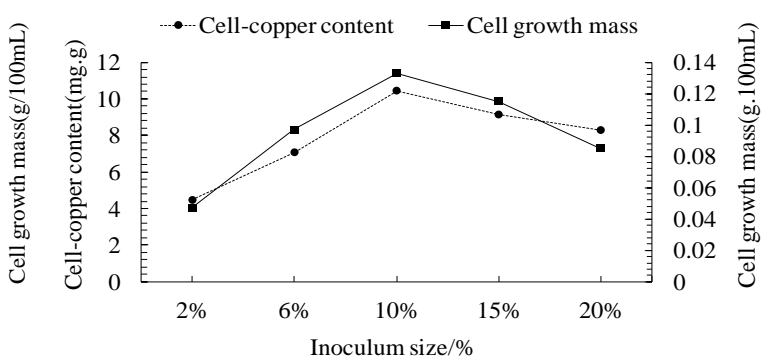

D

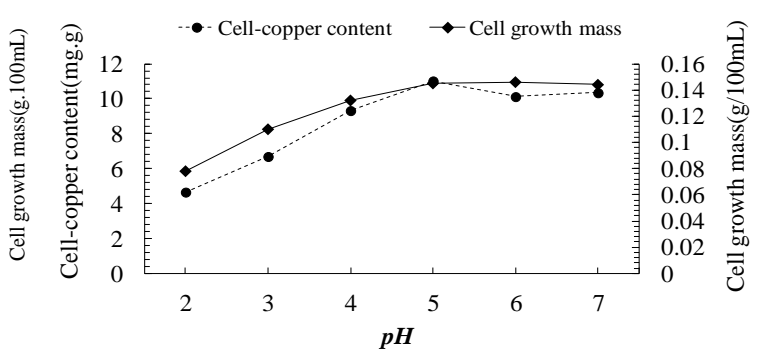

Figure 3. Effects of different factors on copper enrichment and growth of Aspergillus sp. N-2 strain. In here, A-D represent the cell-copper content and cell growth mass at different inoculum size (A), different culture time (B), different $\mathrm{pH}(\mathrm{C})$ and different temperatures (D), respectively.

Table 1. The scheme and results of parameter optimization with CCD (Central Composite Design)

\begin{tabular}{lcccc}
\hline Order & $\mathrm{pH}$ & Temperature $\left({ }^{\circ} \mathrm{C}\right)$ & Inoculum size $(\%)$ & Cell copper content $(\mathrm{mg} / \mathrm{g})$ \\
\hline 1 & 3.00 & 37.00 & 6.00 & 5.54 \\
2 & 7.00 & 37.00 & 6.00 & 6.68 \\
3 & 3.00 & 20.00 & 6.00 & 5.83 \\
4 & 7.00 & 20.00 & 6.00 & 8.51 \\
5 & 3.00 & 37.00 & 20.00 & 6.85 \\
6 & 7.00 & 37.00 & 20.00 & 6.84 \\
7 & 3.00 & 20.00 & 20.00 & 9.07 \\
8 & 7.00 & 20.00 & 20.00 & 10.21 \\
9 & 2.00 & 28.00 & 13.00 & 5.45 \\
10 & 8.00 & 28.00 & 13.00 & 9.23 \\
11 & 5.00 & 15.00 & 13.00 & 1.23 \\
12 & 5.00 & 42.00 & 13.00 & 7.05 \\
13 & 5.00 & 28.00 & 2.00 & 9.12 \\
14 & 5.00 & 28.00 & 25.00 & 13.45 \\
15 & 5.00 & 28.00 & 13.00 & 14.12 \\
16 & 5.00 & 28.00 & 13.00 & 13.45 \\
17 & 5.00 & 28.00 & 13.00 & \\
\hline
\end{tabular}

According to the regression analysis results: The response value had a maximum value; the contour lines between each parameter were elliptic; the interaction was significant; the highest point was visible (see Figure. 4). These results revealed a significant interaction among different conditions, including $\mathrm{pH}$, inoculum, and temperature. Therefore, we analyzed the factors, particularly, $\mathrm{pH}$, temperature, and inoculum size, to obtain the optimum conditions. Using the optimization options of the Design Expert8.0.6 software, the optimal conditions were obtained as follows: The inoculum size, $13 \%$; temperature, $28^{\circ} \mathrm{C} ; \mathrm{pH}, 5$. The intracellular copper content of the optimized strain was $13.45 \mathrm{mg} / \mathrm{g}, 24.18 \%$ higher than that of the original strain process. 
Preparation and process...

Table 2. Analysis of variance (ANOVA) for regression model of intracellular copper

\begin{tabular}{lccccc} 
Source & $\begin{array}{c}\text { Degrees of } \\
\text { freedom }\end{array}$ & $\begin{array}{c}\text { Sum of } \\
\text { squares }\end{array}$ & Mean square & $F$ value & $P$ value \\
\hline Model & 9 & 1.25 & 0.14 & 51.98 & 0.0001 \\
$\mathrm{~A}$ & 1 & 0.083 & 0.083 & 30.97 & 0.0008 \\
$\mathrm{~B}$ & 1 & 0.17 & 0.17 & 61.66 & 0.0001 \\
$\mathrm{C}$ & 1 & 0.040 & 0.040 & 14.86 & 0.0063 \\
$\mathrm{AB}$ & 1 & $9.78 \times 10^{-3}$ & $9.78 \times 10^{-3}$ & 3.65 & 0.0977 \\
$\mathrm{AC}$ & 1 & $9.04 \times 10^{-3}$ & $9.94 \times 10^{-3}$ & 3.38 & 0.1088 \\
$\mathrm{BC}$ & 1 & 0.015 & 0.015 & 5.61 & 0.0497 \\
$\mathrm{~A}^{2}$ & 1 & 0.63 & 0.63 & 236.07 & 0.0001 \\
$\mathrm{~B}^{2}$ & 1 & 0.29 & 0.29 & 109.79 & 0.0001 \\
$\mathrm{C}^{2}$ & 1 & 0.32 & 0.32 & 119.16 & 0.0001 \\
Residual & 7 & 0.019 & $2.68 \times 10^{-3}$ & & \\
Lack of fit & 5 & 0.16 & $3.15 \times 10^{-3}$ & 2.11 & 0.3525 \\
Pure Error & 2 & $2.99 \times 10^{-3}$ & $1.50 \times 10^{-3}$ & & \\
Cor Total & 16 & 1.27 & & & \\
\hline
\end{tabular}

Note: $\mathrm{A}, \mathrm{B}$ and $\mathrm{C}$ represent $\mathrm{pH}$, temperature and inoculum size, respectively.
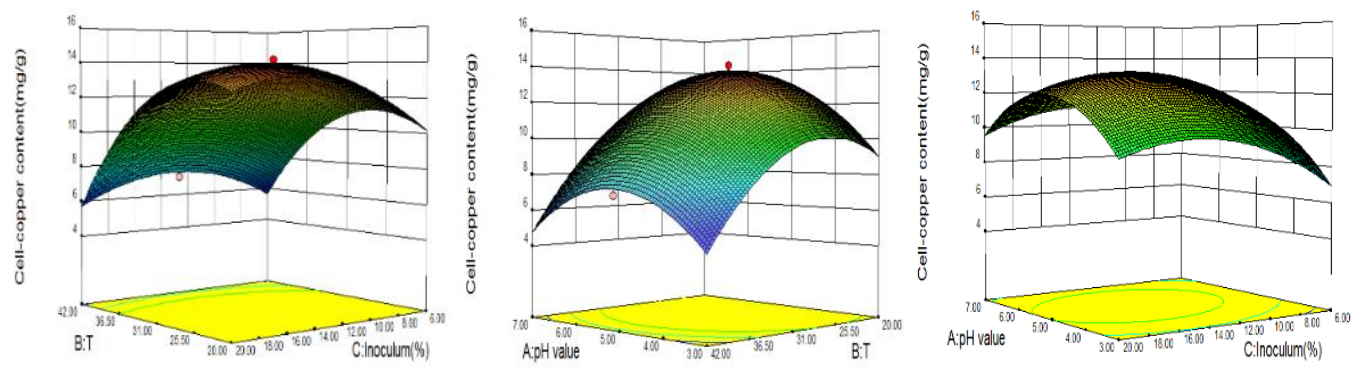

Figure 4. Response surface diagram for the effect of fermentation conditions on copper content in Aspergillus sp. N-2 strain.

\section{DISCUSSION}

Microorganisms with natural copper enrichment potential exist in the environment. Such microorganisms can adsorb metals either via extracellular or intracellular enrichment (Ge et al., 2011; Dong et al., 2014). Gansu Baiyin, also known as "China's Copper City," have major copper deposits located in the volcanic system in the eastern Caledonian Trough in North Qilian. Based on the assumption that strains with high copper transformation potentially exist, a method for screening copper-rich microorganisms from the soil was established. The final screened tolerance of the microorganisms to copper was thrice higher than that of beer yeast $(500 \mathrm{mg} / \mathrm{L})$, reaching $1600 \mathrm{mg} / \mathrm{L}$. Besides, its intracellular copper content was high, at $22.84 \mathrm{mg} / \mathrm{g}$. This screening method provided a novel avenue for further research on organic trace element additives and uncovered a specific application prospect.
Of note, the strain described in this study exhibited a higher conversion rate for $500 \mathrm{mg} / \mathrm{L}$ inorganic copper, and the residual inorganic copper in the medium was the lowest. The process was optimized considering the scaling up of production in the future. Thereafter, the intracellular copper content increased by $31.99 \%$. However, further process optimization is warranted at the time of scale-up. When three subsequent repeated experiments were conducted, the intracellular copper content of the cells concurred with the results of the CCD experimental design. This validated the accuracy and reliability of the optimal fermentation conditions based on the CCD experimental design, thus has a practical value.

In the early stage of this study, although the cells were repeatedly centrifuged and washed with deionized water six times, copper in the culture solution was not completely eliminated (Anahid et al., 2011). Therefore, for organic copper preparation, the following scheme was adopted: 
We cultivated strain N-2 with high copper conversion capacity and collected it via centrifugation at 5,000 r/min for $10 \mathrm{~min}$. After six times wash with $0.9 \%$ sodium chloride solution, the culture was placed in a dialysis bag and dialyzed for $48 \mathrm{~h}$ until no free copper was detected. As the residual organic copper in the dialysis bag is still associated with macromolecular compounds, for example, proteins and polysaccharides in microbial cells, this process ensures that the trace elements obtained are organic copper rather than inorganic copper and organic copper mixtures.

Upon comparing the biomass and intracellular copper content of the strains in different highconcentration copper medium, the target strain with the highest copper enrichment transformation was selected. Further research is required to validate whether other strains with similar or slightly lower intracellular copper content than the target strain can demonstrate better copper enrichment transformation after optimization. Having used only strains selected from the soil near the Baiyin Copper Mine in Gansu, there is a need to explore whether bettertransformed microorganisms are present in soil samples with high copper content in other mining areas.

In this study, based on morphology and molecular analyses, we obtained strain $\mathrm{N}-2$, initially identified as $A$. niger sp., exhibited good copper enrichment and transformation properties. The bacterial colony was black with a protruding and fluffy surface; the mycelium was yellow-white in the early growth period. The spores were dark brown after growth, with spherical conidial spikes. Related studies have shown that A. niger secretes amylase, glucoamylase, citric acid, gluconic acid, gallic acid, and other active substances. Hence, in the food industry, A. niger is mainly used for vinegar brewing (Nicola et al., 2009) and citric acid fermentation (Yang e Zhang, 2010). Moreover, cellulase, hemicellulose, and pectinase produced by A. niger (Papagianni, 2007) can break down cellulose and pectin in plant-derived feed, release nutrients therein, improve the nutritional value of feed, and benefit animals, thus are often used to generate feed additives (Kang et al., 2004).
In combination with biological macromolecules, the organic copper obtained in this study is similar to various enzyme preparation additives used as feed supplements. Although the preparation of conventional feed containing these biomacromolecules may be restricted by granulation and expansion, at present, postaddition technology is widely applied in the feed industry to solve the problem of loss of heatsensitive trace components, such as the added feed drugs and liquid enzyme preparations, due to the associated thermal processing steps (Papagianni, 2007). This technique was first proposed in 1975 and is now widely adopted in several countries (Deng et al., 2002; Zhang e Rong, 2010). Hence, the organic copper obtained via the presently described post-addition process can be incorporated in animal feed in the future.

\section{CONCLUSIONS}

The present study revealed and described a fungus, coded as strain N-2 with good copper enrichment; its transformation properties were screened from a high copper concentration environment. This strain has the highest homology (99\%) to Aspergillus niger based on morphology and molecular methods. Furthermore, this Aspergillus sp. N-2 possesses strong copper enrichment and transformation ability, with intracellular copper content as high as $22.84 \mathrm{mg} / \mathrm{g}$. These results collectively confirmed the existence of strains with better copper enrichment and transformation abilities in the natural environment. Thus, Aspergillus sp. N2 can be exploited as a new copper supplement.

\section{ACKNOWLEDGEMENTS}

This research was supported by the National Natural Science Foundation of China under grant No. 31860004, 31360379, Guiding scientific and technological innovation and development special foundation of Gansu Province (2019ZX-05), and the Fundamental Research Funds for Key Laboratories of Drug Screening and Deep Processing for Traditional Chinese and Tibetan Medicine of Gansu Province (No. 20180802). 


\section{AUTHORS CONTRIBUTION}

Ya-Ru Wei, Guo-Xing wei, Zong-Yuan Wang, Xin-Guo Zhang and Ji Zhang design and executed the study. Dong-Dong Xie helped in data analysis, Xiao-Ying Fan and Zhi-Peng Jia helped in the identification of strains. All authors critically revised the manuscript for important intellectual contents and approved the final version.

\section{REFERENCES}

ADDITIVES, E.P.O; FEED, P.O.S.U.I.A. Scientific Opinion on safety and efficacy of di copper chloride tri hydroxide (tribasic copper chloride, TBCC) as feed additive for all species. EFSA J., v.9, p.2355, 2011.

ANAHID, S.; YAGHMAEI, S.; GHOBADINEJAD, Z. Heavy metal tolerance of fungi. Sci. Iran., v.18, p.502-508, 2011.

BARBULESCU, I.D.; RUSU, N.; RUGHINIS, R. et al. Obtaining yeast biomass enriched with copper, zinc and manganese. Rom. Biotechnol. Letters, v.15, p.5008-5016, 2010.

BRAUDE, R. Some observations on the need for copper in the diet of fattening pigs. J. Agric. Sci., v.35, p.163-167, 1945.

DENG, J.M.; ZHANG, X.; ZHAO, S.M. Afterapplication technology for enzyme preparations. Cereal Feed Ind., v.23, p.18-20, 2002.

DONG, L.H.; WEI, F.S.; LING, Q.Z. et al. Indentification of huperzine A-producing endophytic fungi isolated from Huperzia serrata. World J. Microbiol. Biotechnol., v.30, p.10111017, 2014.

EDULAMUDI, P.; MASILAMANI, A.; DIVI, V.R.S.G., KONADA, V.M. Novel root nodule bacteria belonging to the genus Caulobacter. Lett. Appl. Microbiol., v.53, p.587-591, 2011.

EGRESSY-MOLN, R.O.; GYÓRFI, J.; DERNOVICS, M. et al. Analogy in selenium enrichment and selenium speciation between selenized yeast Saccharomyces cerevisiae and Hericium erinaceus (lion's mane mushroom). LWT Food Sci.Technol., v.68, p.306-312, 2016.

FARNSWORTH, N.R.; AKERELE, O.; BINGEL, A.S. Medicinal plants in therapy. Bull. World Health Organ., v.19, p.336-336, 1984.
GE, W.; ZAMRI, D.; VALIX, M. Bioaccumulation of heavy metals on adapted aspergillus foetidus. Adsorption J. Int. Adsorption Soc., v.17, p.901-910, 2011.

HOU, X.; YAO, S. Improved inhibitor tolerance in xylose-fermenting yeast Spathaspora passalidarum by mutagenesis and protoplast fusion. Appl. Microbiol. Biotechnol., v.93, p.2591-2601, 2012.

KANG, S.; PARK, Y.S.; LEE, J.S. et al. Production of cellulases and hemicellulases by Aspergillus niger KK2 from lignocellulosic biomass. Bioresour. Technol., v.91, p.153-156, 2004.

KNOP, M.; DANG, T.Q.; JESCHKE, G.; SEEBECK, F.P. Copper is a cofactor of the formylglycine $\square$ generating enzyme. Chem. Bio. Chem., v.18, p.161-165, 2017.

KURTZMAN, C.P., FELL, J.W.; BOEKHOUT, T.; ROBERT, V. Methods for isolation, phenotypic characterization and maintenance of yeasts. The Yeasts. 5.ed. Amsterdam: Elsevier, 2011. p.87-110.

LEE, K. M.; YU, J.; SON, M. et al. Transmission of Fusarium boothii mycovirus via protoplast fusion causes hypovirulence in other phytopathogenic fungi. PLoS One, v.6, p.e21629, 2011.

LIU, J.; BAO, W.; JIANG, M. et al. Chromium, selenium, and zinc multimineral enriched yeast supplementation ameliorates diabetes symptom in streptozocin-induced mice. Biol. Trace Elem. Res., v.146, p.236-245, 2012.

LIU, X.; HUA, L.; LIZHOU, M. Application status and development progress of trace elements additives in feed. Feed Ind., v.34, p.28-31, 2013.

LIU, X.; PIAO, J.; YU ZHANG, Y. et al. Serum copper status in school-age children and pregnant women in China nutrition and health survey 2010-2012. Biol. Trace Elem. Res., v.173, p.268274, 2016.

LOTTERMOSER, B.G. Trace metal enrichment in sugarcane soils due to the long-term application of fertilisers, North Queensland, Australia: geochemical and $\mathrm{Pb}, \mathrm{Sr}$, and $\mathrm{U}$ isotopic compositions. Soil Res., v.47, p.311-320, 2009. 
LU, H.Z.; JIA, J.H.; WANG, Q.M.; BAI, F.Y. et al. Candida asparagi sp. nov., Candida diospyri sp. nov. and Candida qinlingensis sp. nov., novel anamorphic, ascomycetous yeast species. Int. J. Syst. Evol. Microbiol., v.54, p.1409-1414, 2004.

MARQUES, R.; COOKE, R.F.; RODRIGUES, M.C. et al. Effects of organic or inorganic cobalt, copper, manganese, and zinc supplementation to late-gestating beef cows on productive and physiological responses of the offspring. J. Anim. Sci., v.94, p.1215-1226, 2016.

MRVČIĆ, J.; STANZER, D.; STEHLIKTOMAS, V. et al. Optimization of bioprocess for production of copper-enriched biomass of industrially important microorganism Saccharomyces cerevisiae. J. Biosci. Bioeng., v.103, p.331-337, 2007.

NICOLA, R.; HALL, N.; BOLLAG, T. et al. Zinc accumulation and utilization by wine yeasts. Int. J. Wine Res., v.1, p.85-94, 2009.

PAPAGIANNI, M. Advances in citric acid fermentation by Aspergillus niger: biochemical aspects, membrane transport and modeling. Biotechnol. Adv., v.25, p.244-263, 2007.

PAŠ, M.; PISKUR, B.; SUSTARIC, M.; RASPOR, P. Iron enriched yeast biomass-A promising mineral feed supplement. Bioresour. Technol., v.98, p.1622-1628, 2007.
WANG, F.; QIU, L.; SHEN, Y.; GE, Y. Investigation and analysis of heavy metal contents from livestock feed and manure in North China. Trans. Chin. Soc. Agricul. Eng., v.31, p.261-267, 2015.

WANG, Z.; ZHANG, J.; SU, T.; GUAN, Z.; JI, M. Screening of iron-and zinc-enriched yeast strain and optimization of cultivation conditions. Prep. Biochem. Biotechnol., v.41, p.278-286, 2011.

WU, X.; ZHANG, T.; LIU, Z. et al. Effects of different sources and levels of copper on growth performance, nutrient digestibility, and elemental balance in young female mink (Mustela vison). Biol. Trace Elem. Res., v.160, p.212-221, 2014.

YANG, Z.; ZHANG, Z. Application of space mutation Aspergillus niger $\mathrm{ZM}-8$ in the production of functionnl bitter buckwheat vinegar. Chin. Brewing, v.254, p.32-34, 2010.

ZHANG, J.F.; RONG, H.Y. Production technique and application of the microbial feed additive in the feeds. Anim. Husbandry Feed, v.31, p.60-63, 2010 .

ZHANG, X.G.; WEI, G.X.; WANG, W.N. et al. Effects of Fe-YM1504 on iron deficiency anemia in rats. Food Funct., v.7, p.3184-3192, 2016. 